\title{
Differences in Types and Technological Means by Which Mexican High Schools Students Perform Cyberbullying: Its Relationship with Traditional Bullying
}

\author{
Angel Alberto Valdés Cuervo ${ }^{1}$, Ernesto Alonso Carlos Martínez ${ }^{2}$, Jesús Tanori Quintana ${ }^{3} \&$ Teodoro Rafael \\ Wendlandt Amezaga ${ }^{1}$ \\ ${ }^{1}$ Instituto Tecnológico de Sonora, Cd. Obregón, Sonora, México \\ ${ }^{2}$ Instituto Tecnológico Superior de Cajeme, Cd. Obregón, Sonora, México \\ ${ }^{3}$ Centro de Investigación en Alimentación y Desarrollo A.C., Hermosillo, Sonora, México \\ Correspondence: Teodoro Rafael Wendlandt Amezaga, Instituto Tecnológico de Sonora, Calle 5 de Febrero, No. \\ 818 Sur, C.P. 85000, Cd. Obregón, Sonora, México. E-mail: wendlandt2012@hotmail.com
}

Received: December 15, 2013 Accepted: February 8, $2014 \quad$ Online Published: March 12, 2014

doi:10.5539/jedp.v4n1p105 URL: http://dx.doi.org/10.5539/jedp.v4n1p105

\begin{abstract}
The aim of this study is to determine the differences between types and technological means by which Mexican high school students perform cyberbullying. The effects to perform the role of aggressor and victim in the traditional bullying were also established in the intensity of the reports of cyberbullying. It was used a random cluster sampling with 278 students selected from four high schools, to which they were given two instruments designed expressly for measuring the frequency of types of cyberbullying and the use of technological means for its realization, as well as the frequency of bullying respectively. Results showed that denigration, harassment and exclusion were reported significantly more strongly than the other types of cyberbullying, and that the most frequently used technological medium were social networks. It was also found that performing the role of aggressor $\left(\mathrm{R}^{2}=.44\right)$ or victim $\left(\mathrm{R}^{2}=.37\right)$ explained a significant portion of the variance of cyberbullying reports. It was concluded that cyberbullying is a phenomenon that can take various forms and it is related in a complex way with traditional bullying.
\end{abstract}

Keywords: cyberbullying, bullying, aggressor, victim

\section{Introduction}

In this study we addressed issues related to cyberbullying during adolescence, considering this stage of life is a central moment in the construction of personal identity. Although there are several factors that contribute to the adolescents' psychosocial adaptation, it has been established that the relationships they maintain with their peers are of particular importance for the development of their personality (Bradford \& Bakken, 2011).

In most cases, the peer relationships during this stage of life represent opportunities for the development of cognitive, emotional and social competences. However, sometimes these relationships become negative experiences causing adverse effects on one or all those involved in a specific situation (Allen, Porter, McFarland, Boykin, \& Marsh, 2007; Pokhel, Sussman, Black, \& Sun, 2010).

The presence of bullying in schools is a clear example of these relationships that can sometimes become negative experiences for those involved in them. In this regard, Stephenson \& Smith (2008) define bullying as a situation in which an individual or group of students intentionally harass a classmate or group of classmates. This phenomenon is characterized by: a) there is a clear difference in power between the aggressor and the victim, b) there is an express intent to inflict physical and/or emotional pain, c) repetitive character and d) has a relational nature (Goossens, Olthof, \& Delkker, 2006; Olweus, 1993).

This problem of violence brings associated negative consequences for everyone involved because it has been found that victims may present difficulties in school performance and its social-emotional development, which can damage their own image, and that even in extreme cases, can lead to suicide (Coloroso, 2004; O'Brennan, Bradshaw, \& Sawyer, 2009). Therefore, during their youth and adult life, aggressors present antisocial behavior 
in their interpersonal relationships, substance abuse, difficulty assuming responsibilities, and even psychiatric disorders (Pearce, 2008; Pepler, Jiang, Craig, \& Connolly, 2008).

The increase in the accessibility and use of Technologies in Information and Communication (TIC) has led to the emergence of a new expression of violence among peers identified as cyberbullying, which is defined as an intentional aggression by a group or an individual to another or others, using for this purpose some technological means of communication (Kessel, O'Donnell, Stueve, \& Coulter, 2012; Solberg, Olweus, \& Endresen, 2007; William \& Guerra, 2007; Willard, 2005). This type of aggression constitutes a type of violence that for being indirect is no less harmful because it has been associated with problems in victims such as: low interest in attending school, loss of concentration in class, absenteeism, emotional difficulties and in generally high levels of stress (Kessel et al., 2012; Li, 2007; García et al., 2012; Sléglova \& Cerná, 2011).

The results of several studies allow to affirm that cyberbullying affects a significant number of students in various regions of the world with percentages being reported ranging from $10 \%$ to $27 \%$ (Beran \& $\mathrm{Li}, 2007$; Buelga, Cava, \& Musitu, 2010; Del Rey, Elipe, \& Ortega, 2012; Slonje \& Smith, 2008). This phenomenon has been also found in Mexico with percentages ranging from $7 \%$ to $20 \%$ in various studies (Del Río, Bringue, Sádaba, \& González, 2009; Lucio, 2009; Vega, González, \& Quintero, 2013; Velázquez, 2009).

Although cyberbullying shares several features with the traditional bullying, it also differs in essential aspects such as greater anonymity by the aggressor and a much larger audience of viewers (Del Rey et al., 2012). These similarities and differences between both types of bullying have led to generate a research line in the field, which seeks to establish the relationship of cyberbullying with various forms of the traditional bullying (Erentaite, Bergman, \& Zukauskiere, 2012; García et al., 2012; Jose, Kljakovic, Scheib, \& Notter, 2011; Junoven \& Gross, 2008; Perren \& Gutzwiller-Helfenfinger, 2012; Slonje \& Smith, 2008).

Studies on the relationship between the two forms of expression of violence among peers, share the characteristics of both, the traditional bullying and the cyberbullying. The results of these studies show the existence of common features in the roles played by both, victims and aggressors, in both types of bullying. However, there is no agreement regarding the magnitude of this relationship, because while some authors refer to it as high (Campbell, 2005; Junoven \& Gross, 2008), others refer to it as moderate, or even low (Erentaité et al., 2012; Hemphill et al., 2012).

In particular, with regard to the relationship of cyberbullying with bullying, findings shown a relationship between: a) being an aggressor in bullying and carry out attacks in the cyberspace ( $\mathrm{Li}, 2007$; Perren \& Gutzwiller-Helfenfinger, 2012); b) be victims of bullying and perform cyberbullying (Erentaité et al., 2012; Jose et al., 2011; Tokunaga, 2010); and c) be a victim of bullying and suffer cyberbullying (Brighi, Guarini, Melotti, Galli, \& Genta, 2012; Jose et al., 2011). The complexity of the relationships between the roles in both groups of behaviors implies the existence of different mechanisms from which it can be expressed the relationship between both phenomena.

\subsection{Formulation of Hypotheses}

In the above context, the study aimed to describe the frequency by which the different types of cyberbullying are presented in Mexican high school students, as well as the technological resources that are used to such behaviors. It also sought to provide elements for understanding the relationship between bullying and cyberbullying, establishing to what extent bullying reports of aggression and victimization may explain the variance in the cyberbullying reports. For this, the present work was based on the following hypotheses:

First hypothesis: There are significant differences in the intensity with which students report doing different types of cyberbullying.

Second hypothesis: There are significant differences in the intensity with which students use the various technological means to conduct cyberbullying.

Third hypothesis: The roles of aggressor and victim in the traditional bullying, explain a significant part of the variance of the cyberbullying reports.

\section{Methodology}

\subsection{Participants}

The population consisted of 1,000 students from four public high schools located in different educational areas of a city in the northwest of Mexico. Of this total, 278 students were selected by a probabilistic sampling by conglomerates. The determination of the size of the sample was based on a probability of success of $50 \%$ and a confidence level of $95 \%(\mathrm{p}=.50 ; \mathrm{q}=.5)$. 
Of all participants, $80(35 \%)$ were studying the second semester, $90(39 \%)$ the fourth and $60(26 \%)$ the last semester (sixth). The average age was 16.8 years with a minimum of 15 and a maximum of 19 years, $46 \%$ were female and $54 \%$ male.

\subsection{Instruments}

Characterization of cyberbullying. The questionnaire developed by Gradinger, Strohmeier and Spiel (2010) was adapted, and some items assessing various types of cyberbullying were included taking in consideration the classification proposed by Willard (2006). These are: a) Harassment, delivery and dissemination of offensive messages; b) Persecution, sending threatening messages; c) Denigration, spreading of shameful rumors about the victim; d) Invasion of privacy, spreading secrets or private images of the victim; e) Social exclusion, prevent the victim to participate in network groups or remove it from them and f) Impersonate the identity, send malicious messages posing as the victim.

The first section (six items) of the questionnaire inquired about the frequency with which students reported having carried out various types of cyberbullying to their peers in the last month. The instrument was answered using a Likert scale ranging from Never, Almost never (one to three times a month), Sometimes (four or five times a month), Almost always (six to 10 times a month) and Always (more than 10 times). It was considered that the answer 'Almost Never' implied a moderate cyberbullying and the answer 'Sometimes' was a severe behavior (Smith et al., 2008). The reliability of the scores measured by Cronbach's alpha was .84 .

The second section (six items) of the questionnaire explored about the frequency with which students reported using electronic means (Cell phone, Facebook, YouTube, Twitter, E-mail) for carrying out the cyberbullying. This scale was answered using a Likert scale with five response options ranging from Never, Almost never, Sometimes, Almost always and Always. The reliability of the scale scores measured by Cronbach's alpha was .85 .

Characterization of bullying. Based on the tools developed by Del Rey \& Ortega (2005) and Raviv et al. (2001), a questionnaire to measure the frequency with which students reported making or receiving aggressive behaviors toward peers during the last month was designed for this study. By means of nine items, the instrument assessed various types of aggressions or victimizations. These are: a) Physical (three items), such as 'Have you ever beaten your peers?' or 'Have your peers beaten you?'; b) Social (three items), for example 'Do you avoid some peers join the games?' or 'Do peers avoid you joining the games?' and c) Psychological (three items), as 'You threat your peers?' or 'Your peers threat you?'.

The responses used a Likert scale ranging from Never, Almost never (one or three times a month), Sometimes (four to five times a month), Almost always (six to 10 times a month) and Always (more than 10 times). The instrument showed reliability by Cronbach's alpha of .88 for the aggressors scale and .85 for the victims.

\subsection{Procedure}

To obtain the data, permission was requested from the authorities of the four high schools as well as written permission was requested from the students' parents to allow them to participate in the research. Finally, after explaining to the students the purpose of the study, they were asked for their voluntary participation, guaranteeing the confidentiality of the information provided by them during the study.

\section{Results}

\subsection{Types of Cyberbullying Reported by Students}

It was observed that students report different types of cyberbullying to their peers at frequencies ranging between $3 \%$ and $16.2 \%$. It should be noted that the highest percentages of cyberbullying behaviors were behaviors manifesting denigration of the victim $(16.2 \%)$ and harassment of the victim $(16.1 \%)$. It was found that the harassment was the type of cyberbullying that students reported to use more frequently in severe form (9.6\%) (see Table 1). 
Table 1. Distribution of the frequencies with which students reported doing different types of ciberbullying

\begin{tabular}{|c|c|c|c|c|c|c|c|c|c|c|c|c|}
\hline \multirow{2}{*}{$\begin{array}{l}\text { Types of } \\
\text { Cyberbullying }\end{array}$} & \multicolumn{2}{|c|}{ Never } & \multicolumn{2}{|c|}{ Almost never } & \multicolumn{2}{|c|}{ Sometimes } & \multicolumn{2}{|c|}{ Almost always } & \multicolumn{4}{|c|}{ Always } \\
\hline & $\mathrm{f}$ & $\%$ & $\mathrm{f}$ & $\%$ & f & $\%$ & f & $\%$ & $\mathrm{f}$ & $\%$ & $\overline{\mathrm{x}}$ & $\overline{\mathrm{ds}}$ \\
\hline Harassment & 233 & 83.9 & 18 & 6.5 & 16 & 5.7 & 7 & 2.6 & 4 & 1.3 & 1.8 & .4 \\
\hline Social exclusion & 242 & 87 & 27 & 9.6 & 6 & 2.2 & 1 & .4 & 2 & .8 & 1.5 & .3 \\
\hline Invasion of privacy & 268 & 96.5 & 4 & 1.3 & 6 & 2.2 & 0 & 0 & 0 & 0 & 1.2 & .4 \\
\hline Persecution & 262 & 94.5 & 6 & 2.1 & 6 & 2.1 & 3 & .9 & 1 & .4 & 1.3 & .2 \\
\hline Denigration & 232 & 83.8 & 32 & 11.4 & 10 & 3.5 & 3 & .9 & 1 & .4 & 1.7 & .3 \\
\hline Impersonate the identity & 269 & 97 & 4 & 1.3 & 4 & 1.3 & 1 & .4 & 0 & 0 & 1.1 & .3 \\
\hline
\end{tabular}

Using a repeated measures ANOVA test, the student responses were compared with respect to the intensity of the different types of cyberbullying. It was found the existance of significant differences in the frequency with which students reported doing different types of cyberbullying $(\mathrm{F}=6.634, \mathrm{p}=.000)$. When using a Post Hoc test, specifically the Bonferroni method, it was established that the means of the behaviors that implied denigration, harassment and exclusion were reported significantly more strongly than the other types of cyberbullying.

\subsection{Technological Means by Which Students Reported Perform Cyberbullying}

It was observed that students report using various technological means to conduct cyberbullying behaviors. Also, it was found that the most common mean for this type of behavior were social networks (see Table 2).

Table 2. Distribution of the frequencies with which students reported using technological means for performing cyberbullying

\begin{tabular}{|c|c|c|c|c|c|c|c|c|c|c|c|c|}
\hline \multirow[t]{2}{*}{ Technological Means } & \multicolumn{2}{|c|}{ Never } & \multicolumn{2}{|c|}{ Almost never } & \multicolumn{2}{|c|}{ Sometimes } & \multicolumn{2}{|c|}{ Almost always } & \multicolumn{4}{|c|}{ Always } \\
\hline & $\mathrm{f}$ & $\%$ & $\mathrm{f}$ & $\%$ & $\mathrm{f}$ & $\%$ & $\mathrm{f}$ & $\%$ & $\mathrm{f}$ & $\%$ & $\overline{\mathrm{x}}$ & $\mathrm{ds}$ \\
\hline Cell phone & 261 & 94 & 10 & 3.5 & 4 & 1.3 & 2 & .8 & 1 & .4 & 1.3 & .2 \\
\hline YouTube & 268 & 96.3 & 4 & 1.3 & 2 & .8 & 2 & .8 & 2 & .8 & 1.1 & .3 \\
\hline Facebook & 229 & 82.5 & 32 & 11.4 & 10 & 3.5 & 6 & 2.2 & 1 & .4 & 1.9 & .3 \\
\hline Twitter & 248 & 89.2 & 17 & 6.1 & 6 & 2.2 & 2 & .8 & 5 & 1.7 & 1.6 & .2 \\
\hline E-mail & 265 & 95.1 & 3 & 1.1 & 3 & 1.1 & 4 & 1.3 & 1 & .4 & 1.1 & .4 \\
\hline
\end{tabular}

Using a repeated measures ANOVA test, the intensities of the students' responses were compared with respect to the technological means used for cyberbullying. Significant differences were found in the frequency with which students reported using various technological means for cyberbullying $(\mathrm{F}=13.81 ; \mathrm{p}=.000)$. Then using Post Hoc tests, particularly the Bonferroni method, it was found that the means used more intensively to carry out this type of behavior were social networks such as Facebook and Twitter, respectively.

\subsection{Relationship between the Roles of Aggressor and Victim of Bullying and Cyberbullying Reports}

The role of aggressor and cyberbullying reports. The existences of significant correlations of each of the independent variables with respect to the dependent variable were confirmed (average of bullying reports in the last month). It was observed that all independent variables obtained positive correlations (statistically significant) with the dependent variable (see Table 3).

Table 3. Correlations between the role of aggressor in bullying and performing cyberbullying

\begin{tabular}{llll}
\hline Bullying & Physical & Psychological & Social \\
\hline Cyberbullying & $.566^{*}$ & $.535^{*}$ & $.540^{*}$ \\
\hline
\end{tabular}

$* \mathrm{p} \leq .05$ 
The assumption that the intensity of the different types of bullying are directly related with the levels of frequencies with which cyberbullying is performed was proven (see Table 4).

Table 4. Results of the regression model for the role of aggressor

\begin{tabular}{llllll}
\hline Model & Sum of squares & $\mathrm{gl}$ & $\mathrm{F}$ & $\mathrm{p}$ \\
\hline Regression & 17.92 & 3 & 56.63 & .000 \\
Residual & 21.94 & 208 & & \\
Total & 39.87 & 211 & & \\
\hline
\end{tabular}

$\mathrm{p} \leq .05$

The results showed that the frequency of cyberbullying is positively associated with the presence of different types of bullying: physical, psychological and social. The $\mathrm{R}^{2}$ was .44 , which implies that the three types of bullying explained the $44 \%$ of the variance in the variance of cyberbullying reports (see Table 5).

Table 5. Variance explaining the different types of bullying from cyberbullying reports

\begin{tabular}{llllll}
\hline & $\begin{array}{l}\text { Standardized } \\
\text { Beta }\end{array}$ & $\mathrm{t}$ & $\mathrm{p}$ & \multicolumn{2}{l}{ Confidence interval (95\%) } \\
\cline { 5 - 6 } & & & Lower & Higher \\
\hline Constant & & 4.304 & .000 & .167 & .448 \\
Psychological & .385 & 4.739 & .000 & .159 & .279 \\
Social & .204 & 3.025 & .003 & .201 & .487 \\
Physical & .168 & 2.170 & .031 & .116 & .343 \\
\hline
\end{tabular}

Note. $R^{2}=.44 ;$ Durbin-Watson $=1.96 ; F=56.34 ; p \leq .05$

The role of victim and cyberbullying reports. It was found that all independent variables showed positive statistically significant correlations with the dependent variable (see Table 6).

Table 6. Correlations between victimization in bullying and the presence of cyberbullying reports

\begin{tabular}{llll}
\hline Bullying & Physical & Psychological & Social \\
\hline Cyberbullying & $.566^{*}$ & $.535^{*}$ & $.540^{*}$ \\
\hline
\end{tabular}

$* \mathrm{p} \leq .05$

It was confirmed the hypothesis that the variables "bullying victimization" and "reports of aggression in cyberbullying" are directly related (see Table 7).

Table 7. Results of the regression model for the role of victim

\begin{tabular}{llllll}
\hline Model & Sum of squares & gl & F & p \\
\hline Regression & 14.31 & 3 & 38.84 & .000 \\
Residual & 25.55 & 208 & & \\
Total & 39.86 & 211 & & \\
\hline
\end{tabular}

$\mathrm{p} \leq .05$

The results showed that the frequency of the presence of cyberbullying is positively associated with the presence of physical, psychological and/or social victimization. The $\mathrm{R}^{2}$ was .37 , which implies that the three types of victimization explained the $37 \%$ of the variance of the reports of frequencies of cyberbullying (see Table 8 ). 
Table 8. Variance explaining the different types of victimization from cyberbullying reports

\begin{tabular}{llllll}
\hline & \multirow{2}{*}{$\begin{array}{l}\text { Standardized } \\
\text { Beta }\end{array}$} & $\mathrm{t}$ & $\mathrm{p}$ & \multicolumn{2}{l}{ Confidence interval (95\%) } \\
\cline { 5 - 6 } & & & & Lower & Higher \\
\hline Constant & & 4.753 & .000 & .216 & .523 \\
Psychological & .168 & 2.170 & .031 & .040 & .269 \\
Social & .347 & 2.919 & .004 & .061 & .317 \\
Physical & .244 & 5.172 & .000 & .202 & .450 \\
\hline
\end{tabular}

Note. $R^{2}=.37 ;$ Durbin-Watson $=1.863 ; F=38.84 ; p \leq .05$

\section{Discussion and Conclusion}

Regarding the first objective of the study, results are consistent with other investigations conducted in the country in the sense of evidencing that cyberbullying is a phenomenon present within high schools in Mexico, even though the percentage of students (16.2\%) that was found involved in this behavior was lower than in previous studies with reported percentages ranging from 20\% to 30\% (Lucio, 2009; Velázquez, 2009). This difference between the results may be explained by the fact that in previous studies that research was conducted with respect to reports of victimization, and in this study was made with regard to reports of aggressions.

Another interesting fact is that social networks were the most common medium used to carry out aggressions; this is not consistent with the findings in other studies in the country in which is reported that the cell phone is the most used for this type of behaviors (Del Río et al., 2009; García et al., 2012). However, the findings of this study are consistent with those reported in other countries in terms of providing evidence of a high usage frequency of social networks regarding the realization of cyberbullying (Grace \& Skonic, 2013; Wheeler, 2011).

The above showed that alongside all the possibilities associated with technological resources for the development of adolescents, there are also potential risks in their uses; one of which is precisely that they are used as a means to carry out aggressions against peers. These facts present the necessity that in Mexico, just like what happens in other countries, greater legislation is necessary to regulate the proper use of technological resources, as well as sanctions which could be obtained by the improper use of these means; also is convenient to develop actions in order to increase the awareness and skills in both, parents and teachers, to monitor the proper use of these technological means by the youth (Paul, Smith, \& Blumberg, 2012; Robinson, 2013; Rose, 2012; Twersky, 2010).

Regarding the third purpose of the study to establish a relationship between traditional bullying and the presence of aggressions in cyberspace, it was found that in bullying both, the role of aggressor and the victim, explain significantly the presence of cyberbullying reports by high school students (Beran \& Li, 2005; Chang et al., 2013; Del Rey et al., 2012).

This shows that the positions of aggressor and victim in bullying constitute risk factors for the realization of cyberbullying. In addition, it is evident that the relationship between both types of phenomena is complex in nature, which implies that different psychological mechanisms may be involved.

Also, it was considered that the relationship between victimization in bullying and cyberbullying, can be explained based on the theory of frustration-aggression developed by Dollard, Doob, Miller, Mowrer, \& Sears (1939), who states that consistent frustration leads to the expression of aggressive behaviors, a fact that has been demonstrated in several studies (Degnan, Calkins, Keane, \& Hill-Soderlund, 2008; Dill \& Anderson, 1995; Wai-Ming \& Taki, 2007).

Moreover, it is contended that the association between the aggressor's role in bullying and the reports of aggressive behavior in cyberspace, provides evidence for the hypothesis that a significant number of the aggressors in bullying show a high ability to understand the states of mind of others and use this information to harm them (Gini, 2006; Sutton, Smith, \& Swettenhan, 1999). This situation is particularly notable in indirect forms of bullying, from which cyberbullying is part, because they involve a greater knowledge of the weaknesses of the victims, same ones that can be used for aggression. The above suggests that the behavior of some of the aggressors does not originate in an empathy poorly developed or social skills deficits, but in the construction of a personal identity, where aggression constitutes a source that the person associates to instrumental and social gains (Gini, 2006; Sijtsema, Veenstra, Lindenberg, \& Salmivalli, 2009). 
Although previous findings require further research to support the hypotheses proposed, the feasibility of these entails the necessity of establishing differentiated interventions with students involved in cyberbullying. However, at least is possible to visualize two lines of action: the first addressed to managing frustration caused by the victimization, this by developing pro-social skills as response; and the second intended for students, so they can visualize new possibilities to build their identity besides that of generating a social climate in school contexts where aggressive behaviors are rejected, and as a consequence, the instrumental and social costs increase.

\section{References}

Allen, J., Porter, M., McFarland, C., Boykin, K., \& Marsh, P. (2007). The relation of attachment to adolescents' paternal and peer relationships, depression, and externalizing behavior. Child Development, 78(4), 1222-1239. http://dx.doi.org/10.1111/j.1467-8624.2007.0162.x

Beran, T., \& Li, Q. (2005). Cyber-harassment: A study of a new method for an old behavior. Journal of Educational Computing Research, 32(3), 265-277. http://dx.doi.org/10.2190/8YQM-B04H-PG4D-BLLH

Bradford, B., \& Bakken, J. (2011). Parenting and peer relationships: Reinvigorating research on family-peers linkages in adolescence. Journal of Research on Adolescence, 21(1), 153-165. http://dx.doi.org/10.1111/j.1532-7795.2010.00720.X

Brighi, A., Guarini, A., Melotti, G., Galli, S., \& Genta, M. (2012). Predictors of victimization across direct bullying, indirect bullying and cyberbullying. Emotional \& Behavioral Difficulties, 17(3-4), 375-388. http://dx.doi.org/10.1080/13632752.2012.704684

Buelga, S., Cava, M., \& Musitu, G. (2010). Cyberbullying: Victimización entre adolescentes a través del teléfono móvil e Internet. Psicothema, 22(4), 784-789. Retrieved from http://www.redalyc.org/articulo.oa?id=72715515039

Campbell, M. (2005). Cyber bullying: An old problem in a new guise? Australian Journal of Guidance and Counselling, 15(1), 68-76. Retrieved from http://eprints.qut.edu.au/1925/1/1925.pdf

Chang, F., Lee, C., Chiu, C., His, W., Huang, T., \& Pen, Y. (2013). Relationships among cyberbullying, school bullying, and mental health in Taiwanese adolescents. Journal of School Health, 83(6), 454-462. http://dx.doi.org/10.1111/josh.12050

Coloroso, B. (2004). The bully, the bullied and the bystander. New York, USA: Harper Colling.

Degnan, K., Calkins, S., Keane, S., \& Hill-Soderlund, A. (2008). Profiles of disruptive behavior across early childhood: Contributions of frustration reactivity, physiological regulation and maternal behavior. Child Development, 29(5), 1357-1376. http://dx.doi.org/10.1111/j.1467-8624-2008.01193.x

Del Rey, R., Elipe, P., \& Ortega, R. (2012). Bullying and cyberbullying: Overlapping and predictive value of the co-occurrence. Psicothema, 24(4), 608-613.

Del Rey, R., \& Ortega, R. (2005). Violencia interpersonal y gestión de la disciplina. Revista Mexicana de Investigación Educativa, 10(26), 805-832. Retrieved from http://www.redalyc.org/articulo.oa?id=14002610

Del Río, J., Bringue, X., Sádaba, C., \& González, D. (2009). Ciberbullying: Un análisis comparativo en estudiantes de Argentina, Brasil, Chile, Colombia, México, Perú y Venezuela. Trípodos, Número Especial, 307-316. Retrieved from http://hdl.handle.net/10171/17800

Dill, J., \& Anderson, C. (1995). Effects of frustration justification on hostile aggression. Aggressive Behavior, 21(5), 359-369. http://dx.doi.org/10.1002/1098-2337(1995)21:5<359::AID-AB2480210505>3.0.CO;2-6

Dollard, J., Doob, L., Miller, N., Mowrer, O., \& Sears, R. (1939). Frustration and Aggression. New Haven, USA: Yale University Press.

Erentaité, R., Bergman, L., \& Zukauskiere, R. (2012). Cross-contextual stability of bullying victimization: A person-oriented analysis of cyber and traditional bullying experiences among adolescents. Scandinavian Journal of Psychology, 53(2), 181-190. http://dx.doi.org/10.1111/j.1467-9450.2011.00935.x

García, G., Martínez, G., Saldívar, A., Sánchez, R., Martínez, G., \& Barrientos, M. (2012). Factores de riesgo y consecuencias del cyberbullying en un grupo de adolescentes. Asociación con el bullying tradicional. Boletín Médico Hospital Infantil México, 69(8), 463-474.

Gini, G. (2006). Social cognition and moral cognition in bullying: What's wrong? Aggressive Behavior, 32(6), 528-539. http://dx.doi.org/10.1002/ab.20153 
Goossens, F., Olthof, T., \& Dekker, P. (2006). New participant role scales: Comparison between various criteria for assigning roles and indications for their validity. Aggressive Behavior, 32(4), 343-357. http://dx.doi.org/10.1002/ab.20133

Grace, K., \& Skonic, M. (2013). Facebook bullying: An extension of battles in school. Computer in Human Behavior, 29(1), 16-25. http://dx.doi.org/10.1016/j.chb.2012.07.014

Gradinger, P., Strohmeier, D., \& Spiel, Ch. (2010). Definition and measurement of cyberbullying. Cyberpsychology: Journal of Psychosocial Research on Cyberspace, 42(1). Retrieved from http://cyberpsychology.eu/view.php?cisloclanku=2010112301\&article=1

Hemphill, S., Kotevski, A., Tollit, M., Smith, R., Herrenkohl, T., Toumbourou, J., \& Catalano, R. (2012). Longitudinal predictors of cyber and traditional bullying perpetration in Australian Secondary School students. Journal of Adolescent Health, 2l(2), 418-428. http://dx.doi.org/10.1016/j.jadohealth.2011.11.019

Jose, P., Kljakovic, M., Scheib, E., \& Notter, O. (2011). The Joint Development of Traditional Bullying and Victimization With Cyber Bullying and Victimization in Adolescence. Journal of Research on Adolescence, 22(2), 301-309. http://dx.doi.org/10.1111/j.1532-7795.2011.00764.x

Junoven, J., \& Gross, E. (2008). Extending the school grounds? Bullying experiences in ciberspace. The Journal of School Health, 78(9), 496-505. http://x.doi.org/10.1111/j.1746-1561.2008.00335.x

Kessel, S., O’Donell, L., Stueve, A., \& Coulter, R. (2012). Cyberbullying, school bullying, and psychological distress: A regional census of high school students. American Journal of Public Health, 102(1), 171-177. http://dx.doi.org/10.2105/AJPH.2011.300308

Li, Q. (2007). New bottle but old wine: A research of cyberbullying in schools. Computers in Human Behavior, 23(4), 1777-1791. http://dx.doi.org/10.1016/j.chb.2005.10.005

Lucio, L (2009). El cyberbullying en estudiantes del nivel medio superior en México. Ponencia X Congreso Nacional de Investigación Educativa. Veracruz, México, COMIE

O'Brennan, L., Bradshaw, C., \& Sawyer, A. (2009). Examining developmental differences in the social-emotional problems among frequent bullies, victims, and bully/victims. Psychology in the Schools, 46(2), 100-115. http://dx.doi.org/10.1002/pits.20357

Olweus, D. (1993). Bullying at school. Australia: Blackwell Publishing

Paul, S., Smith, P., \& Blumberg, H. (2012). Investigating legal aspects of cyberbullying. Psicothema, 24(4), 640-645. Retrieved from http://www.redalyc.org/articulo.oa?id=72723959021

Pearce, J. (2008). ¿Qué se puede hacer con el agresor? In M. Elliot (Ed.), Intimidación. Una guía práctica para combatir el miedo en las escuelas (pp. 157-186). Distrito Federal, México: Fondo de Cultura Económica.

Pepler, D., Jiang, D., Craig, W., \& Connolly, J. (2008). Developmental trajectories of bullying and associated factors. Child Development, 79(2), 325-338. http://dx.doi.org/10.1111/j.1467-8624.2007.01128.x

Perren, S., \& Gutzwiller-Helfenfinger, G. (2012). Cyberbullying and traditional bullying in adolescence: Differential roles of moral disengagement, moral emotions, and moral values. European Journal of Developmental Psychology, 9(2), 195-209. http://dx.doi.org/10.1080/17405629.2011.643168

Pokhel, P., Sussman, S., Black, D., \& Sun, P. (2010). Peer group self-identification as a predictor of relational and physical aggression among high school students. Journal of School Health, 80(5), 249-258. http://dx.doi.org/10.1111/j.1746-1561.2010.00498.x

Raviv, A., Erel, O., Fox, N., Leavitt, L., Raviv, A., Dar, I., Shahinfar, A., \& Greenbaum, C. (2001). Individual measurement of exposure to everyday violence among schoolchildren across various setting. Journal of Community Psychology, 29(2), 117-140. http://dx.doi.org/10.1002/1520-6629(200103)29:2 $<117::$ AID-JCOP1009>3.3.CO;2-U

Robinson, E. (2013). Parental involvement in preventing and responding ti cyberbullying. Family Matters, 1(92), 68-76. Retrieved from http://search.informit.com.au/documentSummary; $\mathrm{dn}=442274761799511$; res $=$ IELHSS

Rose, C. (2012). From LOL to three month in jail: Examining the validity and constitutional boundaries of the Arkansas cyberbullying Act of 2011. Arkansas Law Review, 65(4), 1001-1029. 
Sijtsema, J., Veenstra, R., Lindenberg, S., \& Salmivalli, C. (2009). Empirical test of bullies' status goals: Assessing direct goals, aggression, and prestige. Aggressive Behavior, 35(1), 57-67. http://dx.doi.org/10.1002/ab.20282

Sléglova, V., \& Cerná, A. (2011). Cyberbullying in adolescent victims: Perception and coping. Cyberpsychology: Journal Research on Cyberspace, 5(2). Retrieved from http://cyberpsychology.eu/view.php? cisloclanku=2011121901@ article=4

Slonje, R., \& Smith, P. (2008). Cyberbullying: Another main type of bullying? Scandinavian Journal of Psychology, 49(2), 147-154. http://dx.doi.org/10.1111/j.1467-9450.2007.00611.x

Smith, P., Mahdavi, J., Carvalho, C., Fisher, S., Russell, S., \& Tippett, N. (2008). Cyberbullying: Its nature and impact in secondary school pupils. Journal of Child Psychology and Psychiatry, 49(4), 376-385. http://dx.doi.org/10.1111/j.1469-7610.2007.01846.x

Solberg, M., Olweus, D., \& Endresen, I. (2007). Bullies and victims at school: Are they same pupils? Journal of Educational Psychology, 77(2), 441-464. http://dx.doi.org/10.1348/000709906X105689

Stephenson, P., \& Smith, D. (2008). ¿Por qué algunas escuelas no tienen acosadores? In M. Elliot (Ed.), Intimidación. Una guía práctica para combatir el miedo en las escuelas (pp. 56-78). Distrito Federal, México: Fondo de Cultura Económica.

Sutton, J., Smith, P., \& Swettenham, J. (1999). Bullying and "Theory of Mind": A critique of the "Social Skill

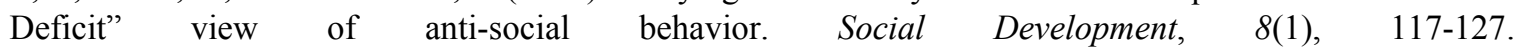
http://dx.doi.org/10.1111/1467-9507.00083

Tokunaga, R. (2010). Following you home from school: A critical review and synthesis of research on cyberbullying victimization. Computers in Human Behavior, 26(3), 277-287. http://dx.doi.org/10.1016/j.chb.2009.11.014

Twersky, A. (2010). On the front lines: Educating teachers about bullying and prevention methods. Journal of Social Sciences, 6(4), 535-539.

Vega, M., González, G., \& Quintero, P. (2013). Ciberacoso: Victimización de alumnos en escuelas secundarias públicas de Tlaquepaque, Jalisco, México. Revista Educación y Desarrollo, 25(2), 13-20.

Velázquez, L. (2009). Cyberbullying. El crudo problema de la victimización en línea. X Congreso Nacional de Investigación Educativa, Veracruz, México, COMIE.

Wai-Ming, F., \& Taki, M. (2007). Bullying among girls in Japan and Hong Kong: An examination of the frustration model. Educational Research and Evaluation, 13(4), 373-399. http://dx.doi.org/10.1080/13803610701702894

Wheeler, T. (2011). Facebook fatalities: Student social networking and the first amendment. Pace Law Review, 31(1), 182-227. Retrieved from http://digitalcommons.pace.edu/plr/vol31/iss $1 / 5$

Willard, N. (2005). Educator's guide to cyberbullying and cyberthreats. Center for Safe and Responsible Internet Use. Retrieved from http://cyberbully.org/docs/cbcteducator.pdf

Willard, E. (2006). Cyberbullying and Cyberthreats: Responding to the challenge of online social cruelty, threats and distress. Oregon, USA: Center for Safe and Responsible Internet Use.

William, K., \& Guerra, N. (2007). Prevalence and predictors of Internet bullying. Journal of Adolescent Health, 41(6), 14-21. http://dx.doi.org/10.1016/j.jadohealth.2007.08.018

\section{Copyrights}

Copyright for this article is retained by the author(s), with first publication rights granted to the journal.

This is an open-access article distributed under the terms and conditions of the Creative Commons Attribution license (http://creativecommons.org/licenses/by/3.0/). 